\title{
SPATIAL DYNAMICS AND DETERMINANT OF FOREIGN DIRECT INVESTMENT IN INDONESIA: A COMPARATIVE STUDY OF PRE AND POST AUTONOMOUS AREA, 1990-2014
}

\author{
Sodik J. ${ }^{1,2 *}$, Sarungu J.J. ${ }^{3}$, Soesilo A.M. ${ }^{3}$, Aisyah S. ${ }^{3}$ \\ ${ }^{1}$ Student of Doctoral Degree Program in Economic Science, Faculty of Economics and \\ Business, University of Sebelas Maret, Surakarta, Indonesia \\ ${ }^{2}$ University of Pembangunan National "Veteran" Yogyakarta, Indonesia \\ ${ }^{3}$ Doctoral Degree Program in Economic Science, Faculty of Economics and Business, \\ University of Sebelas Maret, Surakarta, Indonesia \\ *E-mail: jamzani.sodik@upnyk.ac.id
}

\begin{abstract}
The purpose of this study is to analyze determinant of foreign investment in Indonesia for the period of 1990 to 2014, before and after the implementation of regional autonomy. The analysis method is using a panel data regression throughout Indonesia with provincial analysis unit, Entrophy Theil Index and GIS analysis, which is divided into two intervals ie, before the 1990-2000 regional autonomy, and after the 2001-2014 regional autonomy. Factor that affect the determinant of foreign investment in Indonesia are Market Size indicators (GDP of province and population of province), Resources indicators (labor force and human capital) and Competitiveness indicators (installed electric power, long road, wages, and level of economic openness). The analysis result using GLS fixed-effect method showed that only two significant indicator of the determinant of foreign investment which are Resources and Competitiveness indicator. The results of the analysis before and after the regional autonomy shows that the pattern of spread of foreign investment between the provinces in Indonesia tends to be spread with the dispersal patterns shaped " $U$ " upside down. This reflects that the spatial distribution pattern of foreign investment uneven. These findings provide the conclusion that decentralization has not had a positive impact on the development of foreign investment in Indonesia.
\end{abstract}

\section{KEY WORDS}

Market size, competitiveness, resources, regional autonomy, investment.

In terms of regional development, investment plays an important role to drive economic growth. Investment generally, both in the form of domestic investment (PMDN) and foreign investment (PMA), requires the presence of a healthy climate as well as ease and clarity of investment procedures. Regional economic development dynamics have so far been driven by domestic consumption, but it should also be driven by investment and export. Thus, it requires a conducive investment climate (Kuncoro, 2004). According to Tambunan, (2006), a conducive investment climate is a climate that encourages a person to make investment with the lowest cost and risk that are possible, yet with high long-term benefits. In addition, there are various factors that affect whether the investment climate in Indonesia is good. These factors are related to not only its political and social stability, but also economic stability, basic infrastructure conditions (electricity, telecommunications, road and port infrastructure), well-functioning financial sector and labor market (including labor issues), regulation and taxation, bureaucracy (in terms of time and cost that are created), good governance issues including corruption, consistency and the certainty of government policy.

Data of the last five years from 2011-2015 show that the inflow of foreign investment in Indonesia was very striking. Java Island attracted 57 percent of the accumulated foreign investment worth US $\$ 43542.23$ million. On the other hand, other areas such as Borneo Island only reached 14 percent valued at US\$ 7987.94 million. Sumatera Island reached 13 percent worth US\$ 7733.98 million and Sulawesi Island reached 5 percent or US\$ 3424.38 million (see Table 1). 
Table 1 - Development of Foreign Direct Investment Realization by Island in 2011-2015 (US\$ Million)

\begin{tabular}{|c|c|c|c|c|c|c|c|}
\hline No & Region & 2011 & 2012 & 2013 & 2014 & 2015 & Total Number \\
\hline 1 & Sumatera & 2076.56 & 3729.29 & 3395.35 & $3,844.6$ & $3,732.8$ & 7733.98 \\
\hline 2 & Jawa & 12324.54 & 13659.92 & 17326.38 & $15,436.7$ & $15,433.0$ & 43542.23 \\
\hline 3 & Bali dan Nusa Tenggara & 952.65 & 1126.55 & 888.87 & 993.4 & $1,265.1$ & 3513.87 \\
\hline 4 & Kalimantan & 1918.85 & 3208.65 & 2773.4 & $4,673.6$ & $5,842.9$ & 7987.94 \\
\hline 5 & Sulawesi & 715.26 & 1507.03 & 1498.16 & $2,055.7$ & $1,560.4$ & 3424.38 \\
\hline 6 & Maluku & 141.54 & 98.77 & 321.23 & 111.8 & 286.2 & 583.2 \\
\hline 7 & Papua & 1345.14 & 1234.47 & 2414.16 & $1,414.0$ & $1,155.7$ & 3080.37 \\
\hline
\end{tabular}

Source: Indonesia Statistic in period of 2011-2015, reprocessed.

Java in general is more attractive to foreign investors compared to other regions because it has a number of attractiveness such as the availability of adequate facilities and infrastructure, abundant labor, as well as relatively better transportation and information access. The development of investment for Foreign Direct Investment (PMA) which has been approved in the last five years (2011-2015) shows that FDI was still concentrated in Java, especially in DKI Jakarta, West Java, Banten and East Java (see Table 2).

Table 2 - Development of FDI Realization in Java Island in 2011-2015 (US\$ Million)

\begin{tabular}{|c|c|c|c|c|c|c|c|}
\hline No & Region & 2011 & 2012 & 2013 & 2014 & 2015 & Total \\
\hline 1 & DKI Jakarta & $4,824.08$ & 4107.72 & 2591.13 & $4,509.36$ & $3,619.39$ & $19,651.69$ \\
\hline 2 & Jawa Barat & $3,839.36$ & 4210.70 & 7124.88 & $6,561.95$ & $5,738.71$ & $27,475.60$ \\
\hline 3 & Jawa Tengah & 174.96 & 241.51 & 464.30 & 463.36 & 850.40 & $2,194.53$ \\
\hline 4 & DIY & 2.41 & 84.94 & 29.58 & 64.89 & 89.11 & 270.92 \\
\hline 5 & Jawa Timur & $1,312.04$ & 2298.78 & 3396.26 & $1,802.51$ & $2,593.38$ & $11,402.96$ \\
\hline 6 & Banten & $2,171.69$ & 2716.26 & 3720.23 & $2,034.63$ & $2,541.97$ & $13,184.78$ \\
\hline \multicolumn{2}{|c|}{ Total } & $12,324.54$ & 13659.92 & 17326.38 & $15,436.69$ & $15,432.96$ & $74,180.48$ \\
\hline
\end{tabular}

Source: Indonesia Statistic in period of 2011-2015, reprocessed.

The fact that foreign direct investment is concentrated in Java Island has become interesting when Indonesia is developing regional autonomy policies. When local governments are expected to be self-sufficient in developing their regions, the reality shows that only less than $1 / 4$ (quarter) of the regions are economically self-sufficient because these regions happen to have natural resources. However, the rests are still facing difficulties in meeting the needs for capital and investment to carry out economic development in their regions (Kurniawan, 2002).

Regarding the broad implementation of regional autonomy (Otda) since 2001, after the change of the New Order regime to the Reform Era, there are many hopes for changes and it becomes a turning point to change the relationship pattern from dominant-dependent to mutually interdependent pattern. The spirit to change the relationship pattern among these regions must be promoted by both the central and regional governments, supported by systematic and serious efforts to achieve it. If the inter-regional relationship pattern has changed to become mutually interdependent, all regions will contribute optimally to the national economic development and economic growth, and at the same time minimizing inter-regional economic disparities.

Nonetheless, after sixteen years of regional autonomy, equity in development has not yet been achieved; inter-regional development disparities continue to occur. Without any correction, inter-regional development disparities will continue to occur. Java and Sumatera still get more than 2/3 GRDP distribution of the total national GDP. Inter-regional development disparities are still occuring in Indonesia because its economic activity tends to be geographically concentrated in the Western Region of Indonesia in the last 5 decades. BPS data in 2015 showed that spatial economic activity was still dominated by provinces in Java Island which contributed 58.27 percent, followed by Sumatera Island of 22.37 percent, but the Eastern Region of Indonesia (KTI) only contributed the rest of about 17.96 percent. 
Table 3 below shows the detailed roles of regions/islands in the composition of the national GDP.

Table 3 - The Roles of Regions/lslands in National GDP Composition (Percent)

\begin{tabular}{|c|c|c|c|c|c|}
\hline Regional & 2011 & 2012 & 2013 & 2014 & 2015 \\
\hline Sumatera & 23,5 & 23,74 & 23,81 & 23,63 & 22,37 \\
\hline Jawa & 57,6 & 57,65 & 57,99 & 58,51 & 58,27 \\
\hline Bali dan Nusa Tenggara & 2,6 & 2,51 & 2,53 & 2,58 & 3,38 \\
\hline Kalimantan & 9,6 & 9,30 & 8,67 & 8,21 & 7,99 \\
\hline Sulawesi & 4,6 & 4,74 & 4,82 & 4,97 & 5,01 \\
\hline Maluku dan Papua & 2,1 & 2,06 & 2,18 & 2,10 & 2,98 \\
\hline Total & 100 & 100 & 100 & 100 & 100 \\
\hline
\end{tabular}

Source: Indonesia Statistic in period of 2011-2015, reprocessed.

Foreign Direct Investment (FDI) is defined as long-term investments made directly by foreign investors in a business field of domestic citizens. The investment in the form of FDI is a relatively stable investment in a long-term period. There are several types of FDI as follows: 1) FDI vertical. FDI made vertically involves geographical decentralization of a company's production flow. The company will carry out its production activities in a country with low labor costs, then the products produced in that country will be brought back to the host country. For example, a product whose production process is capital intensive will move its production process to a country that is rich in capital. 2) Horizontal FDI. FDI made horizontally will produce the same products in several countries. The motivation of this type of FDI is to search for new markets. The benefit of this type of FDI is efficiency in transportation costs because the production site is closer to its consumers.

The decision of foreign investors to make investment in the form of FDI compared to other forms of investment in a country is influenced by several conditions of the host country of FDI (pull factor) that may include market conditions, resources, competitiveness, trade and industry-related policies as well as FDI policies. In addition, there are also the conditions and strategies of foreign investors (push factors) that make investment (Kurniati, Prasmuko, \& Yanfitri, 2007). According to Ohlin, traditional trading theory considers FDI as a form of international capital movement. The presence of inter-country relative differences of labor and capital may cause differences in rate of return of capital as stated in the interest rate. This encourages capital movement from rich to poor countries.

Spatial Dynamics of Investment. A study by Sarungu, (2008) in Indonesia has interesting findings in terms of the spatial distribution pattern of investment by island and archipelago categories. Although Sumatera, Borneo, and other islands in Indonesia show changes in the distribution patterns in the direction that tends to spread, Sulawesi Island shows a pattern that tends to be concentrated. Even Java Island, which becomes the largest investment attractiveness in Indonesia because of both government policies and economic infrastructure facilities that are more adequate compared to other regions, shows the distribution pattern of investments that tends to be concentrated. This way, it is time to make efforts in order to achieve equitable distribution of development activities, and the results are also seen from the perspective of the islands and archipelago, instead of only seen from the perspective of the Western Region (KBI) and Eastern Region (KTI) of Indonesia.

Kang, An, \& In, (2008) conducted a study in China. The study results show that regional policy on FDI in China has had an impact, so the FDI disparity decreased from $24 \%$ in 1989 to $13 \%$ in 2005; indicating that the regional policy on the inflow of FDI becomes less influential in China, resulting in regional FDI disparity. It is necessry to have changes in regional preferential policy that dominates all other factors in reducing regional disparity.

A study by Castro, (2007) in Argentina indicates the importance of the effect of regional size (in this case it is shown by the weighted average of distance GPP/ the number of citizens in the neighboring provinces) and domestics as well as the regional public infrastructure (for example paved roads) in determining the spatial distribution of FDI. A study by Hao Huang and Y.H. Dennis Wei, (2011) in China shows that institutional, transportation, 
and agglomeration are the main factors determining the location of FDI in China. However, Guangdong, Pan-YRD and BRR have different factors in determining its concentration. Institutional is the most influential factor on the investments in Guangdong; transportation is the most influential factor in Pan-YRD, and agglomeration affects most of the investments in BRR area. This study shows the importance of certain policies that are appointed by the central government. A comparison of spatial and temporal changes of FDI in Guangdong, Pan-YRD and BRR shows the importance of national government incentives, especially in the early stages.

A study by Firdaus, (2010) in Indonesia shows that there are several spatial determinants of foreign direct investment inflows, namely: market size, economic development level, infrastructure, and educational attainment level; these are statistically significant in attracting foreign investors to come to a province. Investment is proven to play an important role in overcoming regional disparity issues. Government should prioritize some efforts to attract foreign direct investment to the province. Some of the remote areas and eastern parts of Indonesia should be given larger incentives because regional policies have not been effective in attracting foreign investors. These policies include preferential policies in taxation, preferential policies in land use, increase in government and local investment in expanding foreign investment in the remote and eastern parts of Indonesia. The central government should pay more attention to the development of infrastructure and improvement of educational programs in the remote and eastern parts of Indonesia.

Determinants of Investment. A study by Chidlow, Salciuviene, \& Young, (2009) in Poland shows that, first, regional autonomy in Poland has relatively made a difference in the attractiveness for foreign direct investment, regional potential, and economic development. Second, governments should focus on both short-term and long-term measures that are designed to strengthen economic fundamentals and institutional systems. Local governments with the highest attractiveness for FDI will be suggested to focus on efforts to improve their investment climate through political, economic and institutional reforms in their regions.

Ang, (2008) examined the determinants of FDI in Malaysia. The results are consistent with the findings of Asiedu, (2002) and Fedderke \& Romm, (2004), where greater trade liberalization may be conducive to foreign direct investment. FDI inflows react negatively to the increase in corporate tax rates. This result is in accordance with the opinion that reducing corporate tax rates is an effective policy instrument to increase FDI. Interestingly, macroeconomic uncertainty seems to encourage FDI inflow, this way, the study results imply that the composition of FDI may have shifted towards a more speculative foreign investment that is not necessarily pro-growth.

Kok, (2009) conducted a study in developing countries. The results show that appropriate domestic policies will help attract FDI and maximize its benefits, and at the same time also remove obstacles to local business. Foreign corporations, similar to those in the host country, search for a good business environment. Foreign corporations tend to look for regions that offer government incentives, transparency and accountability. Therefore, it is essential for local governments and companies to provide a credible and effective framework for the society, environment, and the local citizens' lives.

A study by Chiang, (2010) was carried out with a case study in China. The results confirm the compatibility with the theory, i.e. the presence of positive effect of economic infrastructure and agglomeration on FDI. Econometric model also shows that the political capacity of provincial government may become an important factor that influences the inflows of FDI. Apart from increasing the resolution of the theory of FDI location to local level, this study also discusses the importance of political considerations in terms of international production. Further, the findings also indicate that development level is positively significant in model 2 but not in model 1. The measurement of infrastructure (transportation and human resources) has a positive and significant effect to attract FDI inflow. Empirical results confirm the positive effect of infrastructure and agglomeration on FDI inflows. Econometric model shows that the political capacity of provincial government may become important to influence the inflow of FDI in China. 
A study conducted by Liu, Daly, \& Varua, (2012a) in China shows a diverse picture, for example we found that market size becomes a priority for FDI inflows into coastal and northeastern regions, while the level of openness is the most important determinant of FDI inflows in the central regions. The quality of labor does not have any impact in the central region but has a positive impact on the FDI inflows in the coastal and northeastern regions. This result has important implications for Chinese regional policymakers as it can help them identify the types of industries that respond specifically as well as identify any regional socioeconomic characteristics that are more attractive for FDI inflows.

Rho, T, NanJoo, P. (2012) conducted a study in Korea with an analysis unit of provinces and foun that the location characteristics (endowment) of each region at the time of FDI inflow influence the final decision regarding location selection. In addition, a study by Liu, Daly, \& Varua, (2012b) in China revealed that market size, labor quality, and government incentives to attract FDI have a positive and significant effect on FDI inflows. On the other hand, high labor costs reduce the attractiveness of an area. Physical infrastructure in the central regions is an important factor to attract FDI becase a large number of low-tech, laborintensive FDI from new industries are concentrated in the central region.

A study by Y. Liu, Daly, \& Varua, (2013) suggests that regional disparities into FDI inflows have important policy implications because there is relationship between FDI inflows and China's economic growth. This study found that the determinants of location in the coastal and northeastern areas are quite similar. In addition, the study also revealed that market size, labor quality, and government incentives to attract FDI have a significant and positive effect on FDI inflows, while high labor costs reduce the attractiveness of a region. Physical infrastructure in the central regions is an important factor to attract FDI.

A study by Trinh, (2013) in Vietnam has contribution to the literature on agglomeration economies, location and foreign direct investment in various aspects. Empirical findings on agglomeration economies are useful for provincial governments in designing policies to attract more foreign direct investments. The results of the study also indicate that provincial characteristics are an important determinant in attracting foreign investors. A study by Fitriandi, Kakinaka, \& Kotana, (2014) has some important implications on public policies intended to attract foreign direct investment in certain provinces in Indonesia. Infrastructure development is needed to increase FDI inflows; the government should pay more attention to the quality of infrastructure development for foreign companies. Apart from that, regarding the fact that a large government spending may drive down FDI inflows due to crowding-out effect, the government should limit its intervention and promote private as well as and private economic activities.

Theil's Coefficient (Entropy Theil Index). To measure variation and diversity of the average investment allocation, coefficient of Theil Entropy Index was used (Kuncoro, 2013). The greater the value, the higher the disparity of investment distribution by province or region. This shows that the distribution pattern is increasingly concentrated in a particular province or region. On the other hand, if the value is closer to 0 , the distribution pattern tends to spread more.

The calculation of the coefficient of Theil Entropy Index was carried out in the following way:

Variation of investment allocation among provinces in all regions in Indonesia:

$$
I(y)=\sum_{i=1}^{N} y_{i} \log \frac{y_{i}}{N}
$$

$\mathrm{I}(\mathrm{y})$ is the overall entropy index of the spatial disparity of investment, yi is the province's share of the total investment in Indonesia, $\mathrm{N}$ is the total number of provinces in Indonesia.

Geographic Information System (GIS). Geographic Information System (GIS) is a specialized information system that manages data that contain spatial information (spatial reference), or in a more narrow sense, it is a computer system that has the ability to build, store, manage and display information that is geographic reference, for example data that 
are identified by location in a database. Another source mentions that GIS is an information system designed to work with spatial reference or geo-coordinated reference data. In other words, GIS is a database system with special ability to handle spatial reference data along with a set of operations (Baba,B and Wiradisastra 2000).

Decrease in Estimation Model. The model used in this study was panel data and translog model (Sun \& Tong, Wilson, 2002) written as follows:

$$
\ln Y_{i t}=\alpha_{i}+\sum \beta_{k} \ln X k_{i t}+\varepsilon_{i t}
$$

Where $Y_{i t}$ is the value of investment, $X_{i t}$ 's is the the determinant of invesment location, $\alpha_{i t}$ is individual effect that is constant between t time and specific for each unit of cross section $\mathrm{i}$. $\mathrm{i}=1,2, \ldots, \mathrm{n}$ refers to the unit of cross section, and $\mathrm{t}=1,2, \ldots, \mathrm{t}$ refers to a given time. Ordinary least square method could give consistent and efficient estimation of $\alpha$ and $\beta$. In addition, the determinants of investment, $X_{i t}$ consists of, the effects of objective economic condition of a region (market, resources, and competitiveness) in a region/province towards the selection of investment location pre and post regional autonomy, so that the translog model turns to be the following:

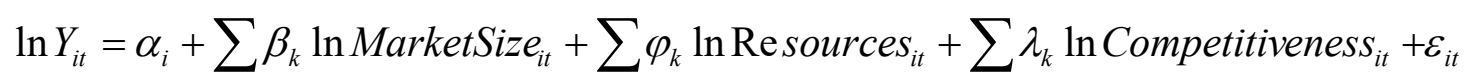

Thus, the determinant of investment location by inserting all the variables could be written as follows:

$$
\begin{aligned}
& \ln Y_{i t}=\alpha_{i}+\beta_{1} \ln x 1_{i t}+\beta_{2} \ln x 2_{i t}+\beta_{3} \ln x 3_{i t}+\beta_{4} \ln x 4_{i t}+\beta_{5} \ln x 5_{i t}+ \\
& \beta_{6} \ln x 6_{i t}+\beta_{7} \ln x 7_{i t}+\beta_{8} \ln x 8_{i t}+\varepsilon_{i t}
\end{aligned}
$$

Where: t: time (1990-2014); i: region/province (26 provinces); Y: the value of FDI realization; X1: regional/provincial GRDP; X2: the number of citizens in a region/province; X3: Workforce is the number of workforce in a region/province; X4: Human Capital is the number of graduates from High School level in a region/province; X5: Electricity installed capacity in a region/province; X6: Length of road in a region/province; X7: UMP is provincial minimum wages; X8: is the level of economic openness (export netto) in a region/province; D Otda: Dummy for Regional Autonomy Policy.

Equation (2) above, $\beta_{1}$ is the elasticity of GRDP and $\beta_{2}$ is the number of citizens that are expected to be positive. Dimension of Resources is workforce $\left(\beta_{3}\right)$, based on the theory, the sign is expected to be positive. Coefficient of human capital $\left(\beta_{4}\right)$ is expected to positively contribute to the disparity of investment. Dimension of Competitiveness is the electricity installed capacity and the length of road that are also expected to contribute positively. So, $\beta_{5}$ and $\beta_{6}$ are expected to have positive signs, while provincial minimum wage is ambiguous $\beta_{7} \neq 0$. Further, economic indicator including export netto $\left(\beta_{8}\right)$ is expected to have positive sign. From the above two models, overall panel data regression (1990-2014) and separation between the time pre autonomy (1990-2000) and post regional autonomy (2001-2014) were done to each, so that it can show the effects of the variables in the models in influencing FDI both before and after regional autonomy.

Estimation Technique. Theoretically, there are several benefits from using the combined data. First, there are more number of observations for the interest of estimating population parameters that bring positive results by increasing the degree of freedom and reducing the possibility of collinearity among independent variables. Second, it is possible to have separate estimation between each individual characteristic and characteristics 
according to time. Therefore, the analysis of estimation results will be more comprehensive since it includes things that are closer to reality (see, Hsiao, 1995).

In the classical linear regression model, error terms are always stated to be homoscedastic and serially uncorrelated. Thus, the use of ordinary least square method will result in the best linear unbiased estimator. Nonetheless, assumptions regarding the error terms cannot be applied to panel data. Panel data, composed of multiple individuals for several periods, bring a new problem in the characteristics of the error terms. The problem is that the current disturbances or error terms are in the form of three types: time-series related disturbances, cross-section disturbances and disturbances coming from both. (see, Gujarati, 2003).

If all the section disturbances $\left(\mu_{\mathrm{i}}\right)$, time disturbances $\left(\lambda_{t}\right)$ and random noise are combined into one and follow all the initial assumptions of random noise that is distributed normally-freely-identically, then the use generalized least square method will produce the best linear unbiased estimators. In other words, this method states that all the disturbances that occur follow a normal distribution, with an expected value of zero, as assumed in the classical linear regression model. This method is well-known as Random Effect Model, or Error Components Model.

However, if the assumption that all the disturbances are stated to not follow the whole assumption of random noise as in the classical linear regression model, then the use of neither ordinary least square or generalized least square model will yield results that satisfy the best linear unbiased characteristics. Thus, the components of time-series disturbances and cross-section disturbances will be combined in the constant of intercept model. This method is known as Fixed Effect Model or also called Dummy Variable Model. This estimation method produces an efficient estimator by applying an estimation process to deviation data from the average by time, the average by sections, and the average by both. Thus, to determine whether to use dummy variables model or error components model, this research used Hausman statistics.

Specification of Hausman Test. The main assumption in regression model is that the component of error or $E\left(u_{i t} / X_{i t}\right)=0$. This is crucial because the factor of disturbance contains invariant individual effect $\left(\mu_{i}\right)$ that is unobserved and possibly correlated with $X_{i t}$. For example, in an equation where $\mu_{i}$ might be denoted as unobservable individually and possible correlated with a number of variables on the right-hand side of the equation. In this case, $E\left(u_{i t} / X_{i t}\right) \neq 0$ and estimator GLS $\left(\hat{\beta}_{G L S}\right)$ will be bias and inconsistent with $\beta$. Even so, by performing transformation $\mu_{i}$ and ignoring it, then estimator $\left(\hat{\beta}_{\text {Within }}\right)$ will be unbiased and consistent with $\beta$. Hausman (1978) suggested to compare $\hat{\beta}_{G L S}$ with $\hat{\beta}_{\text {Within }}$, where both are consistent with null hypothesis $H_{o}: E\left(u_{i t} / X_{i t}\right)=0$, but of course with differences in probability limit. In fact, $\hat{\beta}_{\text {Within }}$ will be consistent even if $H_{o}$ is correct or incorrect, while $\hat{\beta}_{G L S}$ will be BLUE, consistent and asymtotic on $H_{o}$, but will be inconsistent if $H_{o}$ is incorrect. Statistical test will be based on $\tilde{q}_{1}=\hat{\beta}_{G L S}-\tilde{\beta}_{\text {Within }}$, with $H_{o}, p \lim \tilde{q}_{1}=0$ and $\operatorname{cov}\left(\hat{q}_{1}, \hat{\beta}_{G L S}\right)=0$. By considering the fact that $\hat{\beta}_{G L S}-\beta=\left(X^{\prime} \Omega^{-1} X\right)^{-1} X^{\prime} \Omega^{-1} u$ and $\tilde{\beta}_{\text {Within }}-\beta=\left(X^{\prime} Q X\right)^{-1} X^{\prime} Q u$, $E\left(q_{1}\right)=0$ will be obtained:

$$
\begin{gathered}
\operatorname{cov}\left(\hat{\beta}_{G L S}, \hat{q}_{1}\right)=\operatorname{var}\left(\hat{\beta}_{G L S}\right)-\operatorname{cov}\left(\hat{\beta}_{G L S}, \hat{\beta}_{\text {Within }}\right) \\
=\left(X^{\prime} \Omega^{-1} X\right)^{-1}-\left(X^{\prime} \Omega^{-1} X\right)^{-1} X \Omega^{-1} E\left(u u^{\prime}\right) Q X\left(X^{\prime} Q X\right)^{-1}=\left(X^{\prime} \Omega^{-1} X\right)^{-1}-\left(X^{\prime} \Omega^{-1} X\right)^{-1}=0
\end{gathered}
$$


Further, if $\tilde{\beta}_{\text {Within }}=\hat{\beta}_{G L S}-\hat{q}_{1}$, will be obtained $\operatorname{var}\left(\tilde{\beta}_{\text {Within }}\right)=\operatorname{var}\left(\hat{\beta}_{G L S}\right)+\operatorname{var}\left(\hat{q}_{1}\right)$.

Since $\operatorname{cov}\left(\hat{\beta}_{G L S}, q_{1}\right)=0$, then; $\operatorname{var}(\hat{q} 1)=\operatorname{var}\left(\tilde{\beta}_{\text {Within }}\right)-\operatorname{var}\left(\hat{\beta}_{G L S}\right)=\sigma_{v}^{2}\left(X^{\prime} Q X\right)^{-1}-\left(X^{\prime} \Omega^{-1} X\right)^{-1}$. This way, Hausman statistical test is as follows: $m_{1}=\hat{q}_{1}^{\prime}\left[\operatorname{var}\left(\hat{q}_{1}\right]^{-1} \hat{q}_{1}\right.$. Where $H_{o}$ is asymtotic and distributed as $\chi_{K}^{2}$ where $K$ is the dimension of slope vector $\beta$. Next, in order to meet the technical-operational aspect, $\Omega$ will be replaced by the consistency of estimator $\Omega$, so that GLS is possible to perform. The rejection of Hausman statistics means the rejection of fixed effect model or dummy variable model. Thus, the greater the value of Hausman statistics, the greater the possiblity to the acceptance of error components model estimation (Baltagi, 2003).

\section{RESULTS AND DISCUSSION}

Results of Entropy Theil Index. The results of entropy theil index before the implementation of regional autonomy is shown in Table 4 as follows.

Table 4 - Entropy Theil Index of FDI before OTDA

\begin{tabular}{|c|c|}
\hline Years & Theil Index \\
\hline 1990 & 0.198071522 \\
\hline 1991 & 0.349071654 \\
\hline 1992 & 0.329348574 \\
\hline 1993 & 0.176085268 \\
\hline 1994 & 0.2001158 \\
\hline 1995 & 0.165409661 \\
\hline 1996 & 0.053715809 \\
\hline 1997 & 0.15328229 \\
\hline 1998 & 0.176309311 \\
\hline 1999 & 0.364823974 \\
\hline 2000 & 0.279645617 \\
\hline
\end{tabular}

Source: processed data.

Table 4 shows that the total entropy theil index indicates a high spatial disparity of foreign investment before autonomy. Another important finding was that the era between 1990 until 2000 (before regional autonomy) had a pattern of ups and downs, in 1990 it was 0.19 , from 1991 to 1992 there was an increase by 0.34 , then it decreased steadily until 1998 to 0.17 and in 1999 it reached its peak with an index of 0.36 (increased disparity). The substantial increase from 1998 to 1999 shows that, starting in 1999, Indonesia's economy began to recover from the crisis, so investment was also increasing in line with the improvement of macroeconomic conditions. Increased investment will, in turn, encourage an increase in the value of theil entropy index, meaning that the disparity of foreign investment increases. This reflects an uneven spatial distribution pattern of investment in the era prior to regional autonomy (see Figure 1).

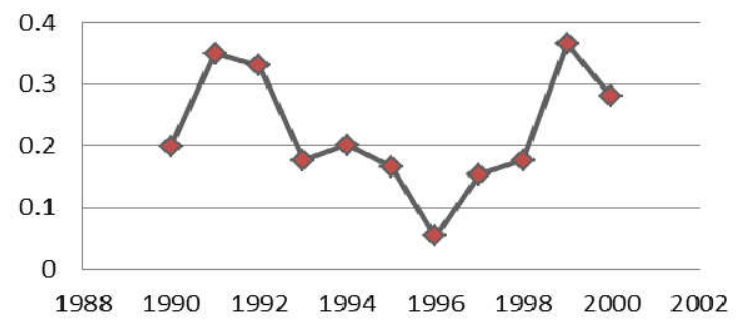

Figure 1 - Trend of Theil Index of FDI before Regional Autonomy 
Figure 1 shows that Theil Entropy Index in 1991 increased then fell to the lowest point in 1996 and rose again until 2000, or formed letter "U". This reflects that there is a dispersion trend of foreign investment before regional autonomy spatially among the provinces in Indonesia. In the period before 1996, there was a declining pattern, reflecting an increase in the spread of FDI in Indonesia. In other words, until 1996, there was evidence that spatial concentration tends to decrease. However, the opposite pattern occurred between 1996 and 2000, where spatial concentration tends to increase. Even in 1998 there was a sharp increase.

The results of entropy theil index after the implementation of regional autonomy is shown in Table 5 as follows.

Table 5 - Theil Entropy Index of FDI after OTDA

\begin{tabular}{|c|c|}
\hline Years & Entrophy Theil Index \\
\hline 2001 & 0.10022149 \\
\hline 2002 & 0.21825783 \\
\hline 2003 & 0.41274667 \\
\hline 2004 & 0.16773457 \\
\hline 2005 & 0.09187596 \\
\hline 2006 & 0.07995996 \\
\hline 2007 & 0.16239832 \\
\hline 2009 & 0.33747562 \\
\hline 2010 & 0.35254287 \\
\hline 2011 & 0.18420002 \\
\hline 2012 & 0.39375384 \\
\hline 2013 & 0.345627475 \\
\hline 2014 & 0.151961085 \\
\hline
\end{tabular}

Source: Processed data.

Table 5 shows that Entropy Theil Index after the era of regional autonomy is fluctuating, indicating that in the era of regional autonomy, each region/province in this study has been competing to get investors. This means that the regions/provinces have been increasingly aware of the importance of investment to increase their regional economic growth. It can be seen that from 2005-2007 there was a decrease (low disparity); in 2008 there was an increase to be 0.33, in 2010 it decreased, in 2011-2012 it increased, and decreased again in 2013-2014 increased slightly (see Figure 2).

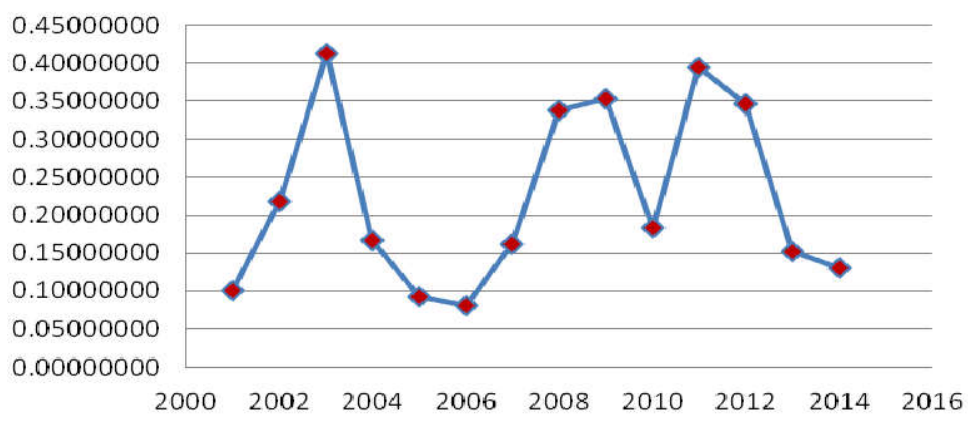

Figure 2 - Trend of Entropy Index of FDI after Regional Autonomy

Figure 2 shows that the distribution pattern of FDI after the implementation of regional autonomy is also fluctuating as that before the implementation of regional autonomy. However, the increase and decrease from year to year is not significant (the disparity is more evenly distributed). An increase only occurred in 2003 (highest position) after the implementation of regional autonomy. The distribution pattern of FDI from 2003 to 2006 decreased (the disparity is increasingly evenly distributed). Then starting in 2007, it 
increased until 2009 (the disparity is uneven). In 2010, it decreased then rose again until 2012, after which it decreased until 2014 (the disparity is more even).

This is possible because after the era of regional autonomy, the regions has more authority to attract investors both domestic and foreign investors, so that each region competes with each other in attracting investors, by marketing their regions. Based on a study by KPPOD-BKPM in 2008, the commitment of local government is the main component that gives the greatest proportion in the establishment of investment climate in the regions. The commitment of local government in creating a conducive climate is important to provide certainty to investors in easily making investment and business expansion.

Results of Geographic Information System (GIS). The distribution of FDI prior to the era of regional autonomy by main islands (\% of total) in 1990 was dominated by Java, Sumatera and Borneo. Then in the next five years or in 1995 there was a change in which it was dominated by Java, Sumatera, Maluku and Papua. This change is mainly due to an increase in FDI in the eastern regions (Maluku and Papua) that is more resource or asset-seeking oriented because these regions are rich in natural resources. In 2000, it was dominated by three islands namely Sumatera, Bali, East and West Nusa Tenggara, followed by Java. This can be seen in Table 1.10. This change is mainly caused by an increase in FDI in Bali, East and West Nusa Tenggara which are associated with the tourism sector because these islands are well-known as a tourist destination in Indonesia even in the world. Thus, this investment can be categorized as market seeking oriented investment. This is shown in Table 6.

Table 6 - Distribution of FDI by Main Region (\%)

\begin{tabular}{|c|c|c|c|}
\hline Region & 1990 & 1995 & 2000 \\
\hline Sumatera & 10.32 & 12.85 & 49.99 \\
\hline Jawa & 73.13 & 64.67 & 19.90 \\
\hline Bali, NTB dan NTT & 6.97 & 0.77 & 25.74 \\
\hline Kalimantan & 8.01 & 3.88 & 2.28 \\
\hline Sulawesi & 1.54 & 5.61 & 1.20 \\
\hline Maluku \& Papua & 0.04 & 12.22 & 0.88 \\
\hline Jumlah & 100 & 100 & 100 \\
\hline
\end{tabular}

Source: Processed data.

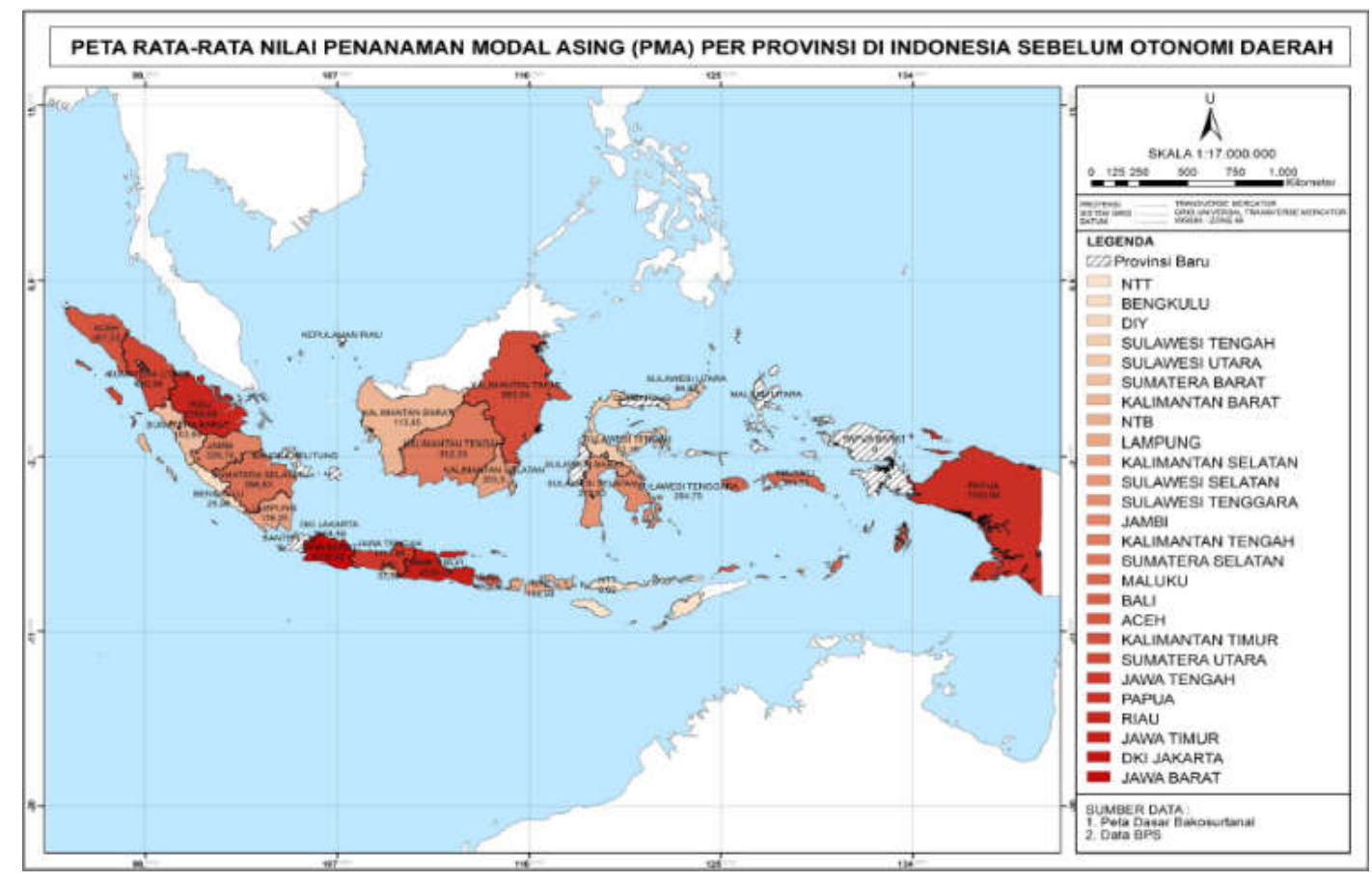

Figure 3 - Map of FDI Distribution before Regional Autonomy 
Figure 3 shows that the distribution of FDI before the implementation of regional autonomy (1990-2000) was dominated by Java Island, followed by Sumatera Island; but slowly Papua Island and Bali Island began to change the dominance. This indicates that the spatial concentration of FDI by islands is still dominated by Java Island, namely the provinces of West Java and East Java and Sumatera Island, namely Riau Province. The spatial concentration of FDI is in line with figure 1.9. where there is a bias to Java Island as the main island and Sumatera Island as the second main island. These findings are in line with a study by (Sarungu, 2008) which found that Java Island, which so far has become the largest center of investment attraction in Indonesia because of both its government policy and its economic infrastructure facilities that are more adequate compared to other regions, is increasingly showing the distribution pattern of investment that tends to be concentrated.

The distribution of FDI after the era of regional autonomy by main islands (\% of total) in 2001 was dominated by Java, Sumatera, Bali, East and West Nusa Tenggara. Then in the next six years or in 2007, it underwent a change where it was dominated by Java, Sumatera and Borneo. In 2012, it was similar to that in 2006: dominated by Java, Sumatera and Borneo Island. The only difference is that Island Borneo increased from 8.92 percent in 2007 to 13.48 percent in 2014. The increase in the percentage of FDI in Borneo Island is dominated by investment in natural resources because this island is rich in natural resources, especially coal. In other words, FDI in Borneo Island has more orientation on resources or asset seeking. This is shown in Table 7.

Table 7 - Distribution of FDI by Main Region (\%)

\begin{tabular}{|c|c|c|c|}
\hline Region & 2001 & 2007 & 2014 \\
\hline Sumatera & 26.04 & 14.74 & 13.48 \\
\hline Jawa & 63.53 & 73.91 & 54.11 \\
\hline Bali, NTB dan NTT & 5.81 & 1.83 & 3.48 \\
\hline Kalimantan & 2.68 & 8.92 & 16.38 \\
\hline Sulawesi & 0.78 & 0.26 & 7.21 \\
\hline Maluku \& Papua & 1.16 & 0.34 & 5.35 \\
\hline Jumlah & 100 & 100 & 100 \\
\hline
\end{tabular}

Source: Processed data.

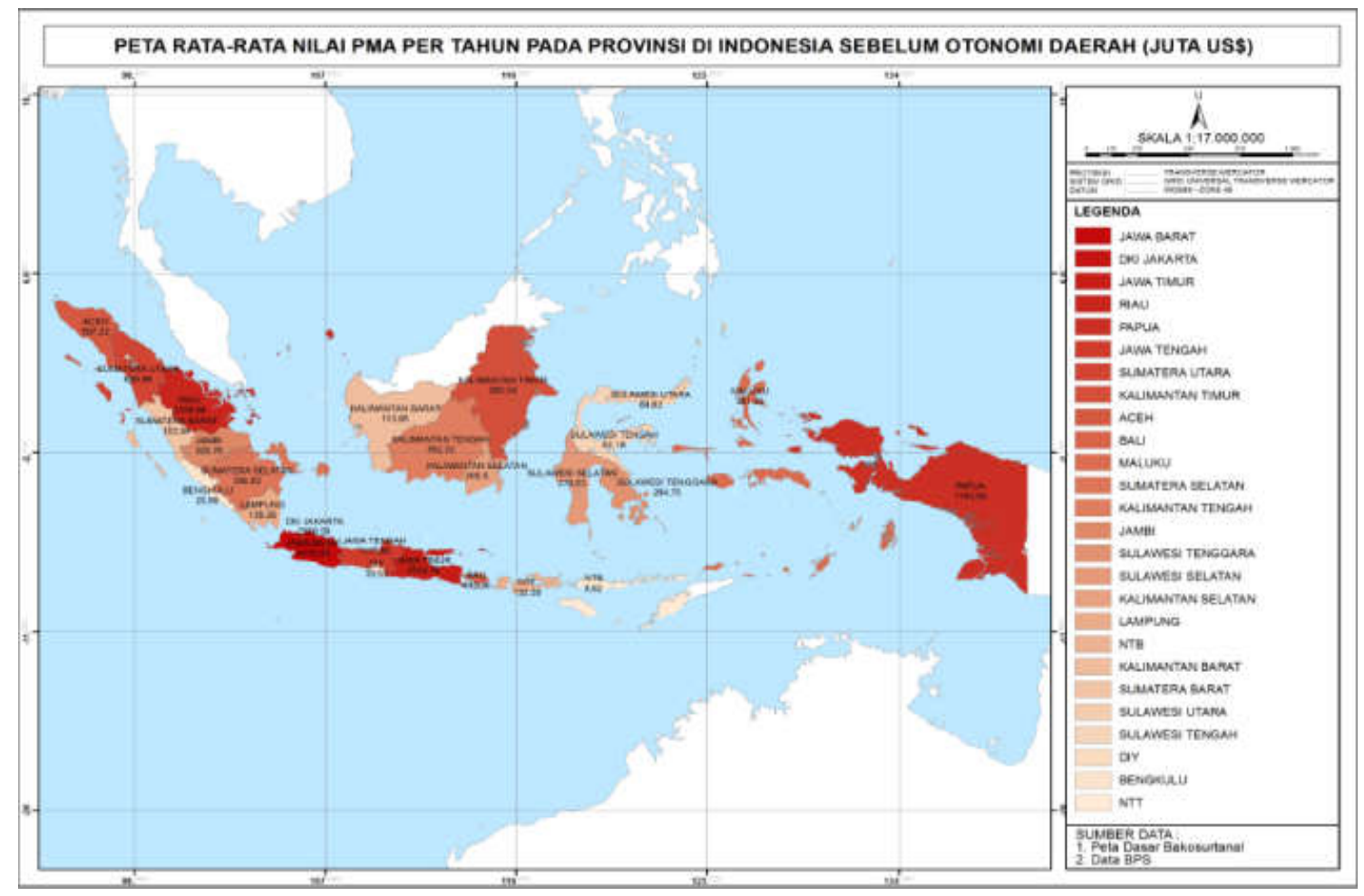

Figure 4 - Map of FDI Distribution after Regional Autonomy 
Figure 4 it can be seen that the distribution of FDI after the implementation of regional autonomy (2001-2012) was dominated by Java Island especially West Java Province, followed by Sumatera Island (Riau Province) and Borneo (East Kalimantan Province). The distribution pattern of FDI after regional autonomy had no significant difference with that before autonomy, indicating that the spatial concentration of investment is still biased to Java Island, as the main island, followed by the second main islands i.e. Sumatera and Borneo Island.

Results of Panel Data Regression. The stage of Hausman test or Hausman statistical test was to test between fixed and random effect approach. Hausman test results for the three periods show that chi square count is greater than chi square table so Ho is rejected. This way, the estimation shows that the fixed effects approach is better than the random effect approach, meaning that there is a difference among units that can be seen through a difference in constant term. In the fixed effects model, it is assumed that there is no timespecific effect and only focuses on individual-specific-effects.

Table 8 - Hausman Test

\begin{tabular}{|c|c|c|}
\hline Period of Observation & X 2 Count & X 2 Table \\
\hline All Data (1990-2014) & $56.927053^{\star \star \star}$ & 20,09 \\
\hline Pre Autonomy (1990-2000) & $58.953258^{\star \star *}$ & 20,09 \\
\hline Post Autonomy (2001-2014) & $233.451563^{\star \star *}$ & 20,09 \\
\hline
\end{tabular}

Source: Processed Data.

Notes: ${ }^{* * *} \operatorname{sig}$ on $\alpha=0.01$.

The estimation results using fixed effect model are presented in the following table:

Table 8 - The Result of Estimation of the Regression Equation of Fixed Effect

\begin{tabular}{|l|l|l|l|}
\hline Variable & Period 1990-2014 (All data) & Period 1990-2000 (Pre Autonomy) & Period 2001-2014 (Post Autonomy) \\
\hline LOG PDRB & $-0.000318^{* * *}$ & $-3.55 \mathrm{E}-05$ & $0.0002050^{*}$ \\
& $(-4.156773)$ & $(-0.213481)$ & $(1.824667)$ \\
LOG JP & $1.64 \mathrm{E}-08^{* * *}$ & $1.85 \mathrm{E}-08^{* * *}$ & $1.00 \mathrm{E}-08^{* * *}$ \\
& $(7.497322)$ & $(2.674948)$ & $(4.544089)$ \\
LOG UMP & $6.19 \mathrm{E}-08^{* *}$ & $1.54 \mathrm{E}-07^{* * *}$ & $4.64 \mathrm{E}-08^{*}$ \\
& $(2.179606)$ & $(2.599870)$ & $(1.900114)$ \\
LOG AK & $0.009206^{* * *}$ & 0.001985 & $0.010581^{* * *}$ \\
& $(25.64417)$ & $(0.975298)$ & $(42.90104)$ \\
LOG EKSP & $1.51 \mathrm{E}-07^{* * *}$ & $1.94 \mathrm{E}-06^{* *}$ & $2.83 \mathrm{E}-08$ \\
& $(3.194558)$ & $(2.028006)$ & $(0.879494)$ \\
LOG DL & $2.76 \mathrm{E}-10$ & $2.79 \mathrm{E}-08^{* *}$ & $1.30 \mathrm{E}-09^{*}$ \\
& $(0.254094)$ & $(2.207583)$ & $(1.819534)$ \\
LOG PJ & $0.000757^{* * *}$ & -0.000643 & $0.000455^{\star * *}$ \\
& $(6.914184)$ & $(-0.622300)$ & $(4.801749)$ \\
LOG HC & $0.000138^{* * *}$ & $0.000351^{* * *}$ & $3.33 \mathrm{E}-05$ \\
& $(5.089244)$ & $(4.848077)$ & $(1.599225)$ \\
D OTDA & $0.807315^{* * *}$ & & \\
\hline F count & $(20.99076)$ & & 84.14369 \\
\hline R 2 count & 24.79916 & 5.742943 & 0.884332 \\
\hline
\end{tabular}

Source: Processed Data.

Notes: ${ }^{* * *} \operatorname{sig}$ on $\alpha=0,01 ;{ }^{* *} \operatorname{sig}$ on $\alpha=0,05 ;{ }^{*} \operatorname{sig}$ on $\alpha=0,10$.

The results of analysis using fixed effect method indicate that, from all the indicators used in this study, the significant indicators to the variable of FDI in Indonesia are Market Size, Competitiveness and Resources.

The dummy variable of regional autonomy affects FDI in Indonesia, indicating that the government's policy on regional autonomy in Indonesia results in the change of FDI. In the current Indonesia's economy, regions are increasingly varying from one another to attract larger amount of investment, especially foreign direct investment. Several provinces or regions absorb more than others. Thus, an important element that makes economic disparity among regions larger is the inflow of investment as a growth engine. Data in the last five 
years from 2011-2015 indicate that the inflows of FDI in Indonesia were very striking. Java attracted 57 percent of foreign direct investment (BPS, 2015).

Indicator of Market Size is significant to FDI in Indonesia in the three observation periods (1990-2014), before regional autonomy (1990-2000) and after autonomy (20012014). This provides evidence that FDI invested in Indonesia aims for market seeking, both domestic-market oriented and export-market oriented. This finding is in line with previous studies. This is reasonable considering that Indonesia has a very large population. In addition, in this study FDI was not differentiated by sectors, so that it is not known which sectors are the most dominant (only using the total FDI in each province). The results of this study are in line with the study by Wahid, Sawkut, \& Seetanah, (2009) in Africa, resulting that abundant natural resources become positive and significant (supporting the presence of resource-seeking FDI) and in line with a study by Asiedu, (2002) and Campos \& Kinoshita, (2008).

Indicator of Resources: the workforce variable has effects with a positive sign, for the whole periods (1990-2014) and the period after regional autonomy (2001-2012). This is in accordance with the existing studies on investment, stating that FDI or MNCs are more interested in coming to a country that has the a large and inexpensive availability of workforce (Hayter, 2000). A study of (Sun \& Tong, Wilson, 2002) in China also provides evidence that the importance of FDI determinants moves over time. The quality of labor and infrastructure is also an important determinant of FDI distribution. High labor quality and good infrastructure attract foreign investors. Such findings indicate that during the period of this study and after the era of regional autonomy, Indonesia has a superior value in the perspective of investors, particularly on the availability of workforce and low labor wages. The human capital Variable also positively influences FDI in provinces in Indonesia for the entire periods (1990-2014) and the period before regional autonomy (1990-2000). This result is in line with a previous study by K. Liu et al., (2012b), showing that quality of labor has a significant and positive effect on FDI inflows. The same study conducted by Raluca, (2010) using the variable of the number of scientists shows a positive and significant relationship with the inflows of FDI. The fact that human capital variable is significant in this study provides evidence that, in the case of the provinces in Indonesia, the existence of human capital in proxies with the number of senior high school graduates may affect foreign direct investment into the provinces. However, for the period after regional autonomy (2001-2014) the variable of human capital has no effect on FDI. This indicates that the FDI that comes to Indonesia after regional autonomy does not recognize the skills of high school graduate workers, so it is necessary for local governments to improve the quality of human resources considering the fact that the quality of human capital is becoming more important in influencing foreign direct investment in Indonesia.

Indicator of Competitiveness: From the variable of electric power and road length for the entire period (1990-2014), only road length was influential. Meanwhile, the variable of electricity installed capacity is significant with a positive sign only before regional autonomy (1990-2000). Although this result is not in line with a previous study Fitriandi et al., (2014), infrastructure in this study has an effect on FDI in Indonesia. A study conducted by Fitriandi et al., (2014)in Indonesia has clear evidence that supports the argument that infrastructure development, in terms of electricity distribution, road length, water distribution, and water capacity, plays an important role in attracting FDI to the provinces in Indonesia. In the period after autonomy (2001-2014), both electric power and road length positively affect FDI in Indonesia, indicating the importance of infrastructure variables on the inflows of FDI to the provinces in Indonesia. This way, infrastructure development in the provinces is a condition to be undertaken by local governments in order to ensure the presence of investment in the regions.

The wage Variable has a positive and significant relationship with the variableof FDI for the entire period of observation (1990-2014), the period before the regional autonomy (1990$2000)$ and the period after the regional autonomy (2001-2014). This positive relationship is because investors currently no longer take into account low wages, but more on production cost efficiency and optimization of the productivity of any existing resources (Hayter, 2000). 
Several studies conducted by Smith \& Florida found that Japanese automotive companies tend to select locations with higher wage rates (Smith, Jr., Donald F., Florida, 1994) . Meanwhile, a study conducted by Kuncoro in Indonesia from 1976-1996 found that wage rates are positively associated with FDI (Kuncoro, 2002). So, it can be stated that the variable explained by the wage does not only have an effect on the cost, but also on skills. This finding was in line with some studies of Changwatchai, (2010), that found the result that the level of wage had a positive correlation with FDI. Nonetheless, for the period after regional autonomy (2001-2012), the variable of wage is not significant. A study from Sun \& Tong, Wilson, (2002) in China provides evidence that the importance of FDI determinants moves over time. Wages had a positive relationship with FDI before 1991. The economic openness Variable has a positive and significant impact on FDI in the provinces for the whole period (1990-2014) and before regional autonomy (1990-2000). The similar result from Wahid et al., (2009) revealed that the openness had a positive impact on FDI and this is in line with the fact that an efficient environment supported with more openness towards the trade might attract the foreign companies. Ang, (2008) found a different result stating that the openness in trade promoted the FDI. Sharma \& Bandara, (2010) showed that the open countries had the larger domestic market and that similar language and culture in Australia have attracted most of foreign investment. The same study by Y. Liu et al., (2013) shows that the more open an economy, the more connected with economic activities throughout the world. Thus, a high level of openness in a region is more attractive for FDI inflows, especially for export-oriented FDI inflows. These findings are in line with several studies conducted by Asiedu, (2002) and Fedderke \& Romm, (2004). Therefore, the results imply that greater trade liberalization is conducive to foreign direct investment.

\section{CONCLUSION AND SUGGESTIONS}

Local governments are expected to issue a new policy that encourages investment at regional level, both domestic and foreign investors, so as to promote regional economic growth and reduce income disparities.

Local governments also need to make coordination about legislative regulations both at the vertical level (among the central-provincial-municipal/regency level government) and at the horizontal level (among any relevant departments and agencies), so that it is necessary to have fundamental reforms related to improving the business climate, export and FDI in Indonesia. The reform agendas that need to be undertaken are: first, to review all local regulations from the provincial and regency/municipal governments in their respective areas regarding investment, second, to have cooperation with the central government and the governments of other provinces in developing procedures and standards for reviewing local regulations related to investment.

The results of this study have some important implications related to public policy aimed at attracting foreign direct investment in several provinces in Indonesia. Infrastructure development is highly needed to increase the inflow of investment; the government should pay more attention to the development and quality of infrastructure for foreign companies. Another policy for the government to attract more investments is to prioritize human resources sector, consisting of education and improvement of human capital.

\section{REFERENCES}

1. Ang, J. B. (2008). Determinants of foreign direct investment in Malaysia. Journal Policy Modeling, 30, 185-189. https://doi.org/10.1016/j.jpolmod.2007.06.014

2. Asiedu, E. (2002). On the Determinants of Foreign Direct Investment to Developing Countries : Is Africa Di erent? World Development, 30(1), 107-119.

3. Baba, B. \& Wiradisastra. (2000). Sistem Informasi Geografis: Sarana Manajemen Sumberdaya. Yogyakarta: Laboratorium Penginderaan Jauh dan Kartografi, Jurusan Tanah, Fakultas Pertanian, IPB.

4. Baltagi, B. H. (2003). Econometric analysis of panel data. England: John Wiley \& Sons, 
LTD. Retrieved from The Atrium, Southerm Gate, Chichester West Sussex PO198SQ,

5. Campos, N. F., \& Kinoshita, Y. (2008). Foreign Direct Investment and Structural Reforms: Evidence from Eastern Europe and Latin America. SSRN Electronic Journal. https://doi.org/10.2139/ssrn.1141849

6. Castro, L. (2007). Infrastructure and the Location of Foreign Direct Investment A Regional Analysis (No. 6736). Retrieved from http://mpra.ub.uni-muechen.de/6736/

7. Changwatchai, P. (2010). the Determinants of Fdi Inflows By Industry To. the University of Utah.

8. Chiang, Y. R. (2010). FDI Location Choice at Provincial China Chiang. International Review of Business Research Papers, 6(5), 274-292.

9. Chidlow, A., Salciuviene, L., \& Young, S. (2009). Regional determinants of inward FDI distribution in Poland. International Business Review, 18(2), 119-133. https://doi.org/10.1016/j.ibusrev.2009.02.004

10. Fedderke, J. W., \& Romm, A. T. (2004). Growth Impact and Determinants of Foreign Direct Investment into South Africa, 1956-2003.

11. Firdaus, M. (2010). Disparity of Investment Inflow among Regions in Indonesia. Economic Journal of Emerging Markets, 2(3), 237-250.

12. Fitriandi, P., Kakinaka, M., \& Kotana, K. (2014). Foreign direct investment and infrastructure development in Indonesia: Evidence from province level data. Asian Journal of Empirical Research, 4(1), 79-94.

13. Gujarati, D. (2003). Basic Econometrics (Third Edit). New York: Mc Graw Hill.

14. Huang, H. \& Wei, Y. H. D. (2011). Spatial-Temporal Patterns And Determinants Of Foreign Direct Investment In China 1 Introduction 2 Theoretical background: comparative ad- vantage , agglomeration economies , and in- stitutional analysis. Erdkunde, 65(1), 723. https://doi.org/10.3112/erdkunde.2011.01.02

15. Hayter, R. (2000). The dynamic of industrial location: The factory, the firm, and the production system. Chichester, John Wiley \& Sons.

16. Hsiao, C. (1995). Analysis of Panel Data. Cambridge, England: Cambridge University Press.

17. Kang, Y. U., An, X. T., \& In, X. X. (2008). Have China â $€^{\mathrm{TM}}$ s FDI Policy Changes Been Successful in Reducing Its FDI Regional Disparity? Journal of World Trade, 42(4), 641653.

18. Kok, R. (2009). Analyses of FDI determinants in developing countries. International Journal of Social, 36, 105-123. https://doi.org/10.1108/03068290910921226

19. Kuncoro, M. (2002). The Economics of Industrial Aggglomeration and Clustering, 19761996: the Case of Indonesia (Java). UGM.

20. Kuncoro, M. (2004). Otonomi dan Pembangunan Daerah: Reformasi, Perencanaan, Strategi, dan Peluang. Jakarta: Erlangga.

21. Kuncoro, M. (2013). Mudah Memahami dan Menganalisis INDIKATOR EKONOMI. Yogyakarta: UPP STIM YKPN.

22. Kurniati, Y., Prasmuko, A., \& Yanfitri. (2007). Determinan FDI. Bank of Indonesia Working Paper, 6, 1-60.

23. Kurniawan, A. B. (2002). Faktor-Faktor Penentu Investasi Asing Langsung Dalam Memilih Lokasi Industri Manufaktur di Pulau Jawa, 1994-1999. UGM.

24. Liu, K., Daly, K., \& Varua, M. E. (2012a). Determinants of Regional Distribution of FDI Inflows across China 's Four Regions. International Business Research, 5(12), 119-126. https://doi.org/10.5539/ibr.v5n12p119

25. Liu, K., Daly, K., \& Varua, M. E. (2012b). Regional Determinants of Foreign Direct Investment in Manufacturing Industry. International Journal of Economics and Finance, 4(12), 178-192. https://doi.org/10.5539/ijef.v4n12p178

26. Liu, Y., Daly, K., \& Varua, M. E. (2013). Determinants of China's Regional FDI Inflows. China-USA Business Review, 12(6), 552-561.

27. Raluca, D. A. (2010). The regional disparities of the fdi in romania. Romanian Economic and Business Review, 5(4), 23-31.

28. Rho, T., NanJoo, P. (2012). A Study on the Determinants of Location Choice in Inward 
Foreign Direct Investment (FDI): Focusing on the Incheon Free Economic Zone. Journal of Modern Accounting and Auditing, 8(4), 488-502.

29. Sarungu, J. J. (2008). Pola Penyebaran Spasial Investasi Di Indonesia: Sebuah Pelajaran Dari Masa Lalu. Jurnal Ekonomi Pembangunan, 9(1), 61-71.

30. Sharma, K., \& Bandara, Y. (2010). Trends, Patterns and Determinants of Australian Foreign Direct Investment. JOURNAL OF ECONOMIC ISSUES, XLIV(3), 661-676. https://doi.org/10.2753/JEI0021-3624440305

31. Smith, Jr., Donald F., Florida, R. (1994). Agglomeration and Industrial Location - An Econometric Analy.pdf. JOURNAL OF URBAN ECONOMICS, 36(1), 23-41.

32. Sun, Q., \& Tong, Wilson, Q. Y. (2002). Determinants of foreign direct investment across China. Journal of International Money and Finance, 21, 79-113.

33. Tambunan, T. (2006). Transformasi Ekonomi di Indonesia, Teori \& Penemuan Empiris. Jakarta: Salemba Empat.

34. Trinh, N. H. (2013). Agglomeration Economies and the Location of Foreign Direct Investment: Empirical Evidence From Vietnam Nam Hoai Trinh. Asian Economics and Financial Review, 3(4), 512-531.

35. Wahid, A. N. M., Sawkut, R., \& Seetanah, B. (2009). Determinants of Foreign Direct Investments ( FDI ): Lessons from the African Economies. Journal of Applied Business and Economics, 9(1), 70-80. 